\title{
014 - Der p 10 as a minor allergen in children sensitised to house dust mites
}

\author{
Isabel Lafuente*, Raquel Pina, Sonia Uixera, Rafael Calderon, Isidoro Cortell, Juan Lopez, Antonio Nieto, \\ Angel Mazon \\ From 3rd Pediatric Allergy and Asthma Meeting (PAAM) \\ Athens, Greece. 17-19 October 2013
}

\section{Objective}

To assess the proportion of children with specific IgE to Der p 10 in children with sensitization to house dust mites (HDM).

\section{Material and methods}

We determined specific IgE (ImmunoCAP ${ }^{\circledR}$, Thermo Fisher Scientific) to Der p 1, Der p 2 and Der p 10 simultaneously in children with symptoms of asthma and/or rhinoconjunctivitis who had positive skin tests to HDM. Values $<0.35 \mathrm{kUA} / \mathrm{L}$ were considered negative.

\section{Results}

We studied 232 children (147 M/85 F) aged 1.25 - 16.7 years. Negative results were found in 50 (21.6\%) with Der p 1, 53 (22.8\%) with Der p 2, 208 (89.7\%) with Der p 10, and 29 with all three (12.5\%). There were 24 patients with positive IgE to Der $p$ 10: three of these had IgE values of 6.1 to $11 \mathrm{kUA} / \mathrm{L}$ to Der $\mathrm{p} 10$ and negative results to Der $\mathrm{p} 1$ and 2 (0.1 to 0.18), three had much higher IgE to Der p 10 (79.9 to $>100)$ than to Der p 1 or $2(0,58$ to 24.2), and one slightly higher IgE to Der p 10 (2.8) than to Der p 1 or 2 (0.8 and 1.19). The rest of the patients had clearly lower IgE to Der $\mathrm{p} 10$.

\section{Conclusion}

About 10\% of patients sensitized to HDM had specific IgE to Der $\mathrm{p} 10$. Sensitization to Der $\mathrm{p} 10$ without sensitization to major allergens Der p 1 and Der p 2 appeared in 1.3\% of patients, and serologically more relevant sensitization to Der p 10 in an additional 1.3\% of patients. This should be considered when prescribing immunotherapy, as Der $\mathrm{p} 10$ is not standardized in current vaccines.

\footnotetext{
Unit of Pediatric Allergy and Pneumology Hospital La Fe, Valencia, Spain
}

Published: 28 February 2014

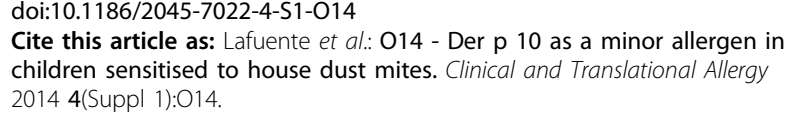

Cite this article as: Lafuente et al: 014 - Der p 10 as a minor allergen in children sensitised to house dust mites. Clinical and Translational Allergy 2014 4(Suppl 1):014.

Submit your next manuscript to BioMed Central and take full advantage of:

- Convenient online submission

- Thorough peer review

- No space constraints or color figure charges

- Immediate publication on acceptance

- Inclusion in PubMed, CAS, Scopus and Google Scholar

- Research which is freely available for redistribution

Submit your manuscript at www.biomedcentral.com/submit
( Biomed Central 